\title{
Cryptococcus tepidarius sp. nov., a thermotolerant yeast species isolated from a stream from a hot- spring area in Japan
}

Correspondence Masako Takashima masako@jcm.riken.jp

\author{
Masako Takashima, ${ }^{1}$ Takashi Sugita, ${ }^{2}$ Yoshimi Toriumi ${ }^{2}$ \\ and Takashi Nakase ${ }^{3}$ \\ ${ }^{1}$ Japan Collection of Microorganisms, RIKEN BioResource Center, Wako, Saitama 351-0198, \\ Japan \\ ${ }^{2}$ Department of Microbiology, Meiji Pharmaceutical University, 2-522-1 Noshio, Kiyose, Tokyo 204- \\ 8588, Japan \\ ${ }^{3}$ NITE Biological Resource Center, Department of Biotechnology, National Institute of Technology \\ and Evaluation, 2-5-8 Kazusakamatari, Kisarazu-shi, Chiba 292-0818, Japan
}

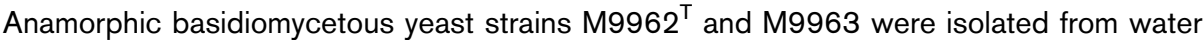
samples collected from a small stream in Ohwakudani, Hakone, a hot-spring area in Japan. These belonged to a single species and were phylogenetically closely related to Bullera lagerstroemiae, although the ability to form ballistoconidia was not observed. Based on sequence analyses of the D1/D2 domain of the LSU rDNA and ITS regions and differences in $G+C$ content, the name Cryptococcus tepidarius sp. nov. Takashima, Sugita, Toriumi et Nakase (Trichosporonales, Tremellomycetes, Basiomycota) is proposed for these isolates, with strain M9962 ${ }^{\top}\left(=\mathrm{SP}-5^{\top}\right.$ $=\mathrm{JCM} 11965^{\top}=\mathrm{CBS} 9427^{\top}$ ) as the type strain. The strains grew in YM broth at $47^{\circ} \mathrm{C}$ and in YM broth with the $\mathrm{pH}$ adjusted to 1.5 by $\mathrm{HCl}$, indicating that the species is thermotolerant and acid-tolerant.
\end{abstract}

\section{INTRODUCTION}

Thermophilic fungi are defined as those that grow above $48{ }^{\circ} \mathrm{C}$ and do not grow below $20{ }^{\circ} \mathrm{C}$ (Watson, 1987). Strains that can grow at temperatures approaching $48{ }^{\circ} \mathrm{C}$ and also below $20{ }^{\circ} \mathrm{C}$ are called methophilic (Watson, 1987), although the term 'thermotolerant' is commonly used for yeasts that can grow at such high temperatures. Thermotolerant yeasts have the advantage that they can be cultured under conditions where other micro-organisms cannot grow, which reduces the risk of contamination. Proteins made by thermotolerant yeasts are also expected to have thermotolerant characteristics. Thermotolerant enzymes made by yeasts may possess special advantages because of their eukaryotic nature, compared with enzymes from thermotolerant bacteria or archaea. The mechanisms by which they are able to grow in more extreme environments, especially as they affect membranes and other lipid systems, are also of interest (Deak, 2006).

Abbreviation: ITS, internal transcribed spacer.

The GenBank/EMBL/DDBJ accession numbers for the ITS region and LSU rDNA D1/D2 domain sequences of strain M9962 ${ }^{\top}$ are AB094045 and AB094046, respectively.

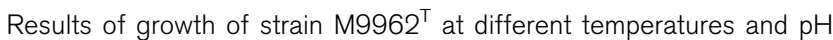
are available as supplementary material with the online version of this paper.
In the course of a study on the diversity of yeast species in various environmental samples, we isolated two thermotolerant, anamorphic, hymenomycetous yeasts from water samples taken from a small stream at Ohwakudani, Hakone, a hot-spring area in Japan. Based on analyses of internal transcribed spacer (ITS) and large-subunit (LSU) rDNA D1/ D2 domain sequences and $\mathrm{G}+\mathrm{C}$ content, these strains were found to represent a novel species phylogenetically related to Bullera lagerstroemiae Fungsin et al. (2006) in the Trichosporonales, Tremellomycetes, Basidiomycota.

\section{METHODS}

Strains M9962 ${ }^{\mathrm{T}}$ and M9963 were isolated on 18 March 2001 from water samples collected from different locations in the stream. Steam is released continuously from the ground in this area, and the atmosphere is sulfurous. Although the $\mathrm{pH}$ and temperature were not measured in the samples, the water in this area is acidic as a result of the presence of sulfuric and/or sulfurous ions (Itoh et al., 2002). Approximately $100 \mu \mathrm{l}$ water was spread on Sabouraud agar plates containing $50 \mu \mathrm{g}$ chloramphenicol $\mathrm{ml}^{-1}$ (Sankyo) and incubated at $27{ }^{\circ} \mathrm{C}$ and colonies were isolated and examined. Most morphological, physiological and biochemical characteristics were examined according to standard methods (Yarrow, 1998). Assimilation of nitrogen compounds was investigated on solid media using a starved inoculum. Vitamin requirements were determined by the method of Komagata \& Nakase (1967). 
Growth temperature. The growth temperature was determined using a temperature-gradient shaking incubator (TVS 126MA; Advantec Toyo). Growth at 12 temperatures between 24 and $60{ }^{\circ} \mathrm{C}$ was determined in YM broth, and optical density at $660 \mathrm{~nm}$ was monitored with the apparatus.

Growth pH range. The growth $\mathrm{pH}$ range was determined using YM broth after adjusting the $\mathrm{pH}$ to values ranging from 1.15 to 8.61 using $\mathrm{HCl}$ or $\mathrm{NaOH}$ and sterilization by filtration. Culture tubes were incubated with shaking and the optical density at $660 \mathrm{~nm}$ was monitored in the Advantec apparatus at a constant temperature of $37^{\circ} \mathrm{C}$.

Major ubiquinone. Cells were grown in $500 \mathrm{ml}$ Erlenmeyer flasks containing $250 \mathrm{ml} \mathrm{YM}$ broth on a rotary shaker at 150 r.p.m. at $25{ }^{\circ} \mathrm{C}$ and were harvested in the early stationary growth phase and then washed with distilled water. Extraction, purification and identification of ubiquinones were carried out according to the method of Nakase \& Suzuki (1986).

DNA G+C content. Cells were grown in $500 \mathrm{ml}$ Erlenmeyer flasks containing $250 \mathrm{ml} \mathrm{YM}$ broth on a rotary shaker at 150 r.p.m. at $25{ }^{\circ} \mathrm{C}$ and were harvested in the exponential growth phase and then washed with distilled water and freeze-dried. Isolation and purification of nuclear DNA were done following Takashima \& Nakase (2000). The DNA base composition was determined by HPLC after enzymic digestion of DNA to deoxyribonucleosides (Tamaoka \& Komagata, 1984). A DNA-GC kit (Seikagaku Corp.) was used as a quantitative standard.
Sequencing and phylogenetic analysis. Nuclear DNA was extracted by the method of Makimura et al. (1994). The ITS regions, including the $5.8 \mathrm{~S}$ rDNA, were amplified by PCR according to Sugita \& Nakase (1999). The D1/D2 domain of the LSU rDNA was amplified following Kurtzman \& Robnett (1997). PCR products were sequenced directly using an ABI Prism BigDye Terminator cycle sequencing ready reaction kit (Applied Biosystems) and analysed with an Applied Biosystems sequencer model 310 according to the manufacturer's instructions. Reference sequences used for the phylogenetic study were obtained from the DDBJ/GenBank/EMBL databases. The sequences were aligned with those of related species using CLUSTAL $\mathrm{w}$ version 1.83 (Thompson et al., 1994) and the alignment was adjusted manually. The phylogenetic tree was constructed using the neighbour-joining method (Saitou \& Nei, 1987). Evolutionary distances were calculated according to Kimura (1980). Sites where gaps existed in any sequences were excluded. Bootstrap analyses (Felsenstein, 1985) for the neighbour-joining method were performed from 100 random resamplings.

\section{RESULTS AND DISCUSSION}

\section{Taxonomic position}

Because strains M9962 ${ }^{\mathrm{T}}$ and M9963 showed identical sequences in the LSU rDNA D1/D2 domain and ITS/5.8S rDNA, these isolates are thought to represent a single species. The phylogenetic tree shown in Fig. 1 is based on

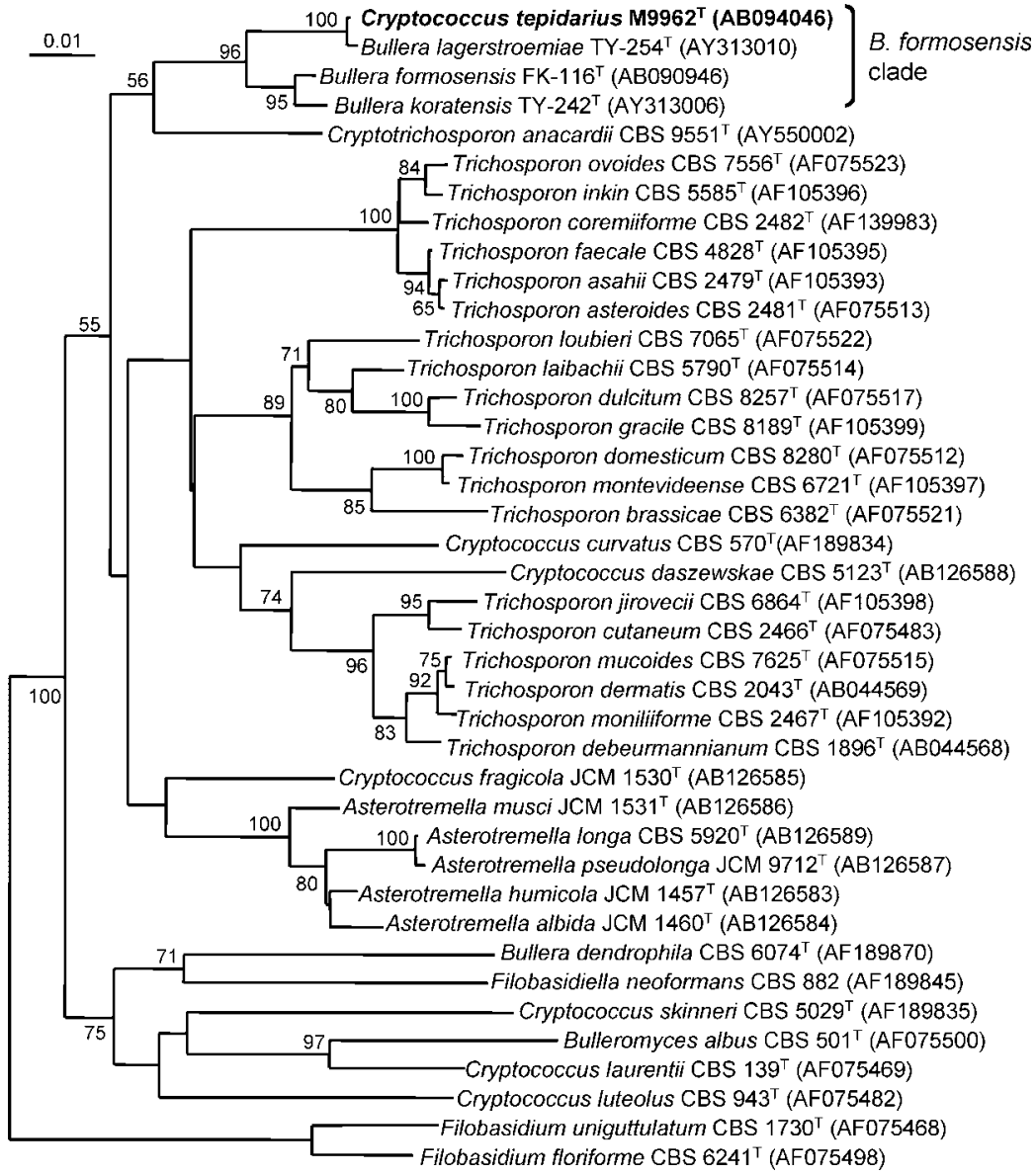

Fig. 1. Neighbour-joining tree of strain M9962 $^{\top}$ (Cryptococcus tepidarius sp. nov.) and related species based on LSU rDNA D1/ D2 domain sequences. Evolutionary distance was calculated according to Kimura (1980). Numerals represent values from 100 replicate bootstrap samplings (values less than 50 not shown). Sequences were retrieved from the DDBJ/GenBank/EMBL databases under the accession numbers indicated. 
sequences of the LSU rDNA D1/D2 domain. Strain M9962 ${ }^{\mathrm{T}}$ formed a clade with Bullera formosensis, Bullera koratensis and B. lagerstroemiae (labelled the B. formosensis clade) in the Trichosporonales, Tremellomycetes, Basidiomycota. Sequence similarities to the type strain of the closest species B. lagerstroemiae were $99.8 \%$ in the LSU rDNA D1/D2 domain (one substitution) and $93.6 \%$ in the overall ITS region (ITS1, 6 substitutions and 2 indels; ITS2, 7 substitutions and 3 indels), indicating that strain M9962 ${ }^{\mathrm{T}}$ is closely related to $B$. lagerstroemiae, but should be regarded as a separate species based on the generalization of Sugita et al. (1999). The DNA G + C content of strain

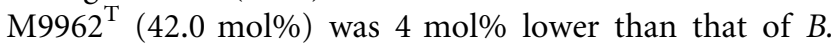
lagerstroemiae, also suggesting separate species status (Kurtzman \& Phaff, 1987). Based on these results, we concluded that our isolates represent a distinct species. The higher growth temperature of this species also supported this separation (Van Uden, 1984). The physiological and biochemical properties of this species were similar to those of B. formosensis, B. koratensis and B. lagerstroemiae, but the latter species differ by their ability to assimilate sodium nitrite and their inability to grow at $37{ }^{\circ} \mathrm{C}$ (Table 1).

The Trichosporonales includes species assigned to the genera Trichosporon, Cryptotrichosporon, Asterotremella, Cryptococcus and Bullera (Fig. 1). Cryptococcus and Bullera are polyphyletic and their nomenclatural types belong to the clade Tremellales (Takashima \& Nakase, 1999; Fell et al., 2000; Fell et al., 2001; Scorzetti et al., 2002). According to the phylogenetic analysis of Okoli et al. (2007), Cryptotrichosporon anacardii occurred at a basal position with respect to the clade designated the $B$. formosensis clade in this paper. Strain $\mathrm{M}_{9} 962^{\mathrm{T}}$ belongs to this clade (bootstrap value 96\%), but whether Cryptotrichosporon anacardii is also a member is not so

Table 1. Distinctive characteristics among Cryptococcus tepidarius sp. nov. and related species

Species/strains: 1, Cryptococcus tepidarius M9962 ${ }^{\mathrm{T}}$; 2, B. formosensis JCM $11142^{\mathrm{T}}$; 3, B. koratensis; 4, B. lagerstroemiae. Data for $B$. koratensis and B. lagerstroemiae were taken from Fungsin et al. (2006). + , Positive; -, negative; L, latent; w, weak; LW, latent and weak; ND, not determined.

\begin{tabular}{|lcccc|}
\hline Characteristic & $\mathbf{1}$ & $\mathbf{2}$ & $\mathbf{3}$ & $\mathbf{4}$ \\
\hline $\begin{array}{l}\text { Assimilation of carbon com- } \\
\text { pounds }\end{array}$ & - & & & \\
$\quad$ L-Sorbose & $\mathrm{L} /+$ & $\mathrm{L}$ & $\mathrm{L}$ & $\mathrm{L} /-$ \\
D-Ribose & - & $\mathrm{L}$ & $\mathrm{L}$ & $\mathrm{LW} /-$ \\
Erythritol & $-/ \mathrm{LW}$ & - & $\mathrm{L}$ & - \\
Saccharate & - & + & + & + \\
Assimilation of sodium nitrite & 42.0 & 57.8 & 49.4 & 46.0 \\
DNA G+C content (mol\%) & $\mathrm{N} .0$ & & & \\
Maximum growth & $\mathrm{ND}(>47)$ & $29-30$ & $29-30$ & $29-30$ \\
temperature $\left({ }^{\circ} \mathrm{C}\right)$ & & & & \\
\end{tabular}

clear (bootstrap value 56\%). Another new genus, Asterotremella, was proposed for Cryptococcus humicola, Cryptococcus longus, Cryptococcus musci and Cryptococcus pseudolongus, in the Trichosporonales (Prillinger et al., 2007). Consequently, phylogenetically poorly defined Cryptococcus species (Cryptococcus curvatus, Cryptococcus daszewskae and Cryptococcus fragicola) and the species in the B. formosensis clade remain in the Trichosporonales (Fig. 1). This situation will remain until a robust multigene study is conducted on this group of basidiomycetous yeasts. Species in the B. formosensis clade appear to be monophyletic.

Based on the above results, we conclude that the species represented by strains M9962 $^{\mathrm{T}}$ and M9963 should provisionally be assigned to the polyphyletic genus Cryptococcus, in agreement with the genus concept of Fell \& Statzell-Tallman (1998), as the ability to form ballistoconidia has not been observed in strains $\mathrm{M} 9962^{\mathrm{T}}$ and M9963. However, it should be transferred to an appropriate genus when a robust phylogeny of the hymenomycetous yeasts is available and the phenotypic characteristics of each genus are better defined. The name Cryptococcus tepidarius sp. nov. is proposed for strains $\mathrm{M}_{9} 962^{\mathrm{T}}$ and M9963.

\section{Thermotolerant and acid-tolerant characteristics}

Our study of the temperature dependence of growth showed that Cryptococcus tepidarius $\mathrm{M} 9962^{\mathrm{T}}$ had almost the same growth profile between 24 and $39{ }^{\circ} \mathrm{C}$ (Supplementary Fig. S1, available in IJSEM Online). The $\mathrm{OD}_{660}$ reached 1.0 within $24 \mathrm{~h}$. At $41.8{ }^{\circ} \mathrm{C}$, growth was delayed slightly compared with $24-39{ }^{\circ} \mathrm{C}$, but good growth was shown within $100 \mathrm{~h}$; growth was also observed at 45.6 and $47.7{ }^{\circ} \mathrm{C}$, although it was further delayed. At 54.9 and $60{ }^{\circ} \mathrm{C}$, no increase in $\mathrm{OD}_{660}$ was detected after $700 \mathrm{~h}$ of incubation. Many ascomycetous yeasts can grow at $40{ }^{\circ} \mathrm{C}$ (Barnett et al., 2000) and Ogataea thermophila, reported to grow at $50{ }^{\circ} \mathrm{C}$ (Shin et al., 2001; Péter et al. 2007), has the highest maximum growth temperature known to date. In the basidiomycetous yeasts, some pathogenic yeasts such as Filobasidiella neoformans are capable of growth at $40{ }^{\circ} \mathrm{C}$. Nagahama et al. (2003) reported that the maximum growth temperature of Rhodotorula benthica and Rhodotorula calyptogenae, isolated from a deep-sea habitat, was 41$44{ }^{\circ} \mathrm{C}$, but neither grew at $45{ }^{\circ} \mathrm{C}$. We therefore conclude that Cryptococcus tepidarius has the highest maximum growth temperature reported so far for a basidiomycetous yeast.

Our study of $\mathrm{pH}$-dependent growth of Cryptococcus tepidarius $\mathrm{M} 9962^{\mathrm{T}}$ showed that good growth occurs at $\mathrm{pH}$ 1.5-8.6, with delayed and weak growth at $\mathrm{pH} 1.2$ (Supplementary Table S1). The general $\mathrm{pH}$ range for growth for yeasts is said to be $\mathrm{pH} 2-7$, with an optimum at pH 4.0-4.5 (Deak, 2006). Walker (1977) reported that a few yeasts involved in food spoilage could grow at lower $\mathrm{pH}$, as low as $\mathrm{pH} 1.5$. We conclude that Cryptococcus 
tepidarius is acid tolerant and that both thermotolerance and acid tolerance might be the result of adaptation to the environment from which the yeasts were isolated (Raspor \& Zupan, 2006).

\section{Latin diagnosis of Cryptococcus tepidarius sp. nov. Takashima, Sugita, Toriumi et Nakase}

In liquido $\mathrm{YM}$, post dies 3 ad $25{ }^{\circ} \mathrm{C}$ cellulae ovoideae, ellipoideae aut elongatae, $3.8-5.5 \times 4.3-10 \mu \mathrm{m}$, singulae, binae, vel parvi-racemosae; post unum mensen ad $17{ }^{\circ} \mathrm{C}$ annullus fragilis, insulae et sedimentum formantur. In agaro $\mathrm{YM}$, post unum mensem ad $17{ }^{\circ} \mathrm{C}$ cultura xanthoalba, glabra, subnitida, mollis aut butyracea, et margo glabra. Mycelium et pseudomycelium non formantur. Fermentatio nulla. Glucosum, galactosum (vel lente), sucrosum, maltosum, cellobiosum, trehalosum, lactosum (lente), raffinosum (lente vel lente et exiguum), melezitosum, amylum solubile, D-xylosum, L-arabinosum, D-arabinosum (vel lente), Dribosum (vel lente), L-rhamnosum, D-glucosaminum (lente), $\mathrm{N}$-acetyl-D-glucosaminum, glycerolum (lente et exiguum vel nullum), ribitolum (vel lente), galactitolum, D-mannitolum, D-glucitolum, methyl- $\alpha$-D-glucosidum, salicinum, glucono- $\delta$ lactonum, acidum D-gluconicum, acidum 2-ketogluconicum, acidum 5-ketogluconicum, acidum DL-lacticum (lente et exiguum vel nullum), acidum succinicum, acidum citricum, inositolum, acidum saccharicum (lente et exiguum vel nullum), xylitolum, L-arabinitolum, acidum D-glucuronicum, et acidum D-galacturonicum assimilantur at non Lsorbosum, melibiosum, inulinum, methanolum, ethanolum, erythritolum, hexadecanum, propane-1,2-diolum nec butane2,3-diolum. L-Lysinum, ethylaminum, et cadaverinum assimilantur at non kalium nitricum nec natrium nitrosum. Cultura crescens ad $45{ }^{\circ} \mathrm{C}$. Ad crescentiam thiaminum necessarium est. Commutatio colori per diazonium caeruleum B positiva. Ubiquinonum majus: Q-10. Proportio molaris in acido deoxyribonucleico: $42.0 \mathrm{~mol} \%$ (per HPLC). Teleomorphosis ignota. Holotypus: Isolatio M9962 ex aqua ad rivulum, Ohwakudani, Hakone, Japonia, Y. Toriumi et T. Sugita, 18/03/2001, in collectionibus culturarum ut JCM 11965 quas Japan Collection of Miroorganisms (JCM), RIKEN, Wako, Saitama, Japonia conservata, item in collectionibus culturarum ut CBS 9427 quas Centraalbureau voor Schimmelcultures (CBS), Trajectum ad Rhenum, Hollandia, conservata.

\section{Description of Cryptococcus tepidarius sp. nov.}

Cryptococcus tepidarius (te.pi.da' ri.us. L. masc. adj. tepidarius of or belonging to tepid water, because the type strain was isolated from water of a tepid stream).

After 3 days in $\mathrm{YM}$ broth at $25^{\circ} \mathrm{C}$, cells are ovoidal, ellipsoidal or elongate, $3.8-5.5 \times 4.3-10 \mu \mathrm{m}$, single, in pairs or in small clusters (Fig. 2). A ring and sediment are formed. After 1 month, a complete and fragile ring, islets and a heavy sediment are produced. After 1 month on YM agar at $17{ }^{\circ} \mathrm{C}$, the streak culture is light yellow, smooth,

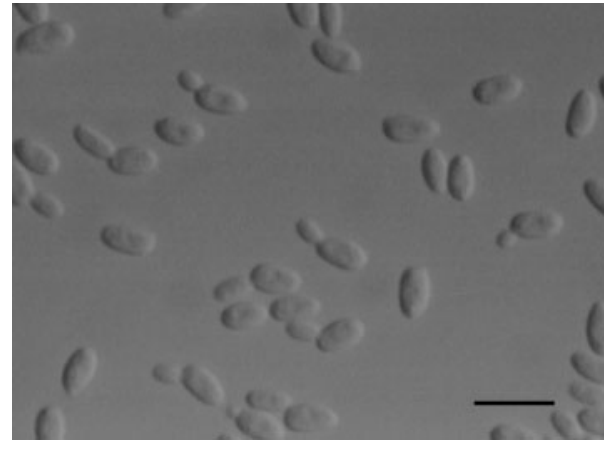

Fig. 2. Vegetative cells of strain $M 9962^{\top}$ grown in $Y M$ broth for 3 days at $25^{\circ} \mathrm{C}$. Bar, $10 \mu \mathrm{m}$.

semi-shiny, soft to butyrous and has an entire margin. Mycelium and pseudomycelium are not formed in slide culture on cornmeal agar. Does not ferment glucose. Assimilates glucose, galactose (or latent), sucrose, maltose, cellobiose, trehalose, lactose (latent), raffinose (latent or latent and weak), melezitose, soluble starch, D-xylose, Larabinose, D-arabinose (or latent), D-ribose (or latent), Lrhamnose, D-glucosamine (latent), $\mathrm{N}$-acetyl-D-glucosamine, glycerol (latent and weak or null), ribitol (or latent), galactitol, D-mannitol, D-glucitol, methyl $\alpha$-D-glucoside, salicin, glucono- $\delta$-lactone, D-gluconate, 2-ketogluconic acid, 5-ketogluconic acid, DL-lactic acid (latent and weak or null), succinic acid, citric acid, inositol, saccharic acid (latent and weak or null), xylitol, L-arabinitol, D-glucuronic acid and D-galacturonic acid. Does not assimilate Lsorbose, melibiose, inulin, methanol, ethanol, erythritol, n-hexadecane, propane-1,2-diol or butane-2,3-diol. Assimilates L-lysine hydrochloride, ethylamine hydrochloride and cadaverine dihydrochloride. Does not assimilate potassium nitrate or sodium nitrite. Thiamine is required for growth. Grows at $45{ }^{\circ} \mathrm{C}$. No starch-like substances are produced. Does not liquefy gelatin, hydrolyse fat, produce acid from glucose or grow on $50 \% \quad(\mathrm{w} / \mathrm{w})$ glucose-yeast extract agar. Urease and diazonium blue $\mathrm{B}$ reactions are positive. Major ubiquinone is Q-10. DNA $\mathrm{G}+\mathrm{C}$ content of the type strain is $42.0 \mathrm{~mol} \%$ (by HPLC).

The type strain, M9962 ${ }^{\mathrm{T}}\left(=\mathrm{SP}-5^{\mathrm{T}}=\mathrm{JCM} 11965^{\mathrm{T}}=\mathrm{CBS}\right.$ $9427^{\mathrm{T}}$ ), was isolated from water collected from a small stream at Ohwakudani, Hakone, Japan, on 18 March 2001 by Y.T. and T.S.

\section{REFERENCES}

Barnett, J. A., Payne, R. W. \& Yarrow, D. (2000). Yeasts: Characteristics and Identification, 3rd edn. Cambridge: Cambridge University Press.

Deak, T. (2006). Environmental factors influencing yeasts. In Biodiversity and Ecophysiology of Yeasts (The Yeast Handbook series), pp. 156-174. Edited by C. A. Rosa \& G. Péter. Berlin: Springer. 
Fell, J. W. \& Statzell-Tallman, A. (1998). Cryptococcus Vuillemin. In The Yeasts, a Taxonomic Study, 4th edn, pp. 742-767. Edited by C. P. Kurtzman \& J. W. Fell. Amsterdam: Elsevier.

Fell, J. W., Boekhout, T., Fonseca, A., Scorzetti, G. \& StatzellTallman, A. (2000). Biodiversity and systematics of basidiomycetous yeasts as determined by large-subunit rDNA D1/D2 domain sequence analysis. Int J Syst Evol Microbiol 50, 1351-1371.

Fell, J. W., Boekhout, T., Fonseca, A. \& Sampaio, J. P. (2001). Basidiomycetous yeasts. In The Mycota, vol. 7, Systematics and Evolution, part B, pp. 3-35. Edited by D. J. McLaughlin, E. G. McLaughlin \& P. A. Lemke. Berlin: Springer.

Felsenstein, J. (1985). Confidence limits on phylogenies: an approach using the bootstrap. Evolution 39, 783-791.

Fungsin, B., Takashima, M., Sugita, T., Artjariyasripong, S., Potacharoen, W., Tanticharoen, M. \& Nakase, T. (2006). Bullera koratensis sp. nov. and Bullera lagerstroemiae sp. nov., two new ballistoconidium-forming yeast species in the Trichosporonales clade isolated from plant leaves in Thailand. J Gen Appl Microbiol 52, 73-81.

Itoh, T., Suzuki, K. \& Nakase, T. (2002). Vulcanisaeta distributa gen. nov., sp. nov. and Vulcanisaeta souniana sp. nov., novel hyperthermophilic, rod-shaped crenarchaeotes isolated from hot springs in Japan. Int J Syst Evol Microbiol 52, 1097-1104.

Kimura, M. (1980). A simple method for estimating evolutionary rates of base substitutions through comparative studies of nucleotide sequences. J Mol Evol 16, 111-120.

Komagata, K. \& Nakase, T. (1967). Microbiological studies on frozen foods. V. General properties of yeasts isolated from frozen foods. Food Hyg Soc Jpn 8, 53-57 (in Japanese).

Kurtzman, C. P. \& Phaff, H. J. (1987). Molecular taxonomy. In The Yeasts, 2nd edn, vol. 1, pp. 63-94. Edited by A. H. Rose \& J. S. Harrison. London: Academic Press.

Kurtzman, C. P. \& Robnett, C. J. (1997). Identification of clinically important ascomycetous yeasts based on nucleotide divergence in the $5^{\prime}$ end of the large-subunit (26S) ribosomal DNA gene. J Clin Microbiol 35, 1216-1223.

Makimura, K., Murayama, Y. S. \& Yamaguchi, H. (1994). Detection of a wide range of medically important fungal species by polymerase chain reaction (PCR). J Med Microbiol 40, 358-364.

Nagahama, T., Hamamoto, M., Nakase, T. \& Horikoshi, K. (2003). Rhodotorula benthica sp. nov. and Rhodotorula calyptogenae sp. nov., novel yeast species from animals collected from the deep-sea floor, and Rhodotorula lysiniphila sp. nov., which is related phylogenetically. Int J Syst Evol Microbiol 53, 897-903.

Nakase, T. \& Suzuki, M. (1986). Bullera megalospora, a new species of yeast forming large ballistospores isolated from dead leaves of Oryza sativa, Miscanthus sinensis and Sasa sp. in Japan. J Gen Appl Microbiol 32, 225-240.

Okoli, I., Oyeka, C. A., Kwon-Chung, K. J., Theelen, B., Robert, V., Groenewald, J. Z., McFadden, D. C., Casadevall, A. \& Boekhout, T. (2007). Cryptotrichosporon anacardii gen. nov., sp. nov., a new trichosporonoid capsulate basidiomycetous yeast from Nigeria that is able to form melanin on niger seed agar. FEMS Yeast Res 7, 339-350.
Péter, G., Tornai-Lehoczki, J., Shin, K. S. \& Dlauchy, D. (2007). Ogataea thermophila sp. nov., the teleomorph of Candida thermophila. FEMS Yeast Res 7, 494-496.

Prillinger, H., Lopandic, K., Sugita, T. \& Wuczkowski, M. (2007). Asterotremella gen. nov. albida, an anamorphic tremelloid yeast isolated from the agarics Asterophora lycoperdoides and Asterophora parastica. J Gen Appl Microbiol 53, 167-175.

Raspor, P. \& Zupan, J. (2006). Yeast in extreme environment. In Biodiversity and Ecophysiology of Yeasts (The Yeast Handbook series), pp. 371-417. Edited by C. A. Rosa \& G. Péter. Berlin: Springer.

Saitou, N. \& Nei, M. (1987). The neighbor-joining method: a new method for reconstructing phylogenetic trees. Mol Biol Evol 4, 406425.

Scorzetti, G., Fell, J. W., Fonseca, A. \& Statzell-Tallman, A. (2002). Systematics of basidiomycetous yeasts: a comparison of large subunit D1/D2 and internal transcribed spacer rDNA regions. FEMS Yeast Res 2, 495-517.

Shin, K.-S., Shin, Y. K., Yoon, J.-H. \& Park, Y.-H. (2001). Candida thermophila sp. nov., a novel thermophilic yeast isolated from soil. Int J Syst Evol Microbiol 51, 2167-2170.

Sugita, T. \& Nakase, T. (1999). Non-universal usage of the leucine CUG codon and the molecular phylogeny of the genus Candida. Syst Appl Microbiol 22, 79-86.

Sugita, T., Nishikawa, A., Ikeda, R. \& Shinoda, T. (1999). Identification of medically relevant Trichosporon species based on sequences of internal transcribed spacer regions and construction of a database for Trichosporon identification. J Clin Microbiol 37, 19851993.

Takashima, M. \& Nakase, T. (1999). Molecular phylogeny of the genus Cryptococcus and related species based on the sequences of $18 \mathrm{~S}$ rDNA and internal transcribed spacer regions. Microbiol Cult Collect $15,35-47$.

Takashima, M. \& Nakase, T. (2000). Four new species of the genus Sporobolomyces isolated from leaves in Thailand. Mycoscience 41, 357369.

Tamaoka, J. \& Komagata, K. (1984). Determination of DNA base composition by reversed-phase high-performance liquid chromatography. FEMS Microbiol Lett 25, 125-128.

Thompson, J. D., Higgins, D. G. \& Gibson, T. J. (1994). CLUSTAL W: improving the sensitivity of progressive multiple sequence alignment through sequence weighting, position-specific gap penalties and weight matrix choice. Nucleic Acids Res 22, 4673-4680.

Van Uden, N. (1984). Temperature profiles of yeasts. Adv Microb Physiol 25, 195-251.

Walker, H. W. (1977). Spoilage of food by yeasts. Food Technol (Champaign) 31, 57-61.

Watson, K. (1987). Temperature relations. In The Yeasts, 2nd edn, vol. 2, pp. 41-71. Edited by A. H. Rose \& J. S. Harrison. London: Academic Press.

Yarrow, D. (1998). Methods for the isolation, maintenance and identification of yeasts. In The Yeasts, a Taxonomic Study, 4th edn, pp. 77-100. Edited by C. P. Kurtzman \& J. W. Fell. Amsterdam: Elsevier. 